\title{
On the Expected and Actual Rhythmical Grammar of Russian Iambic Tetrameter
}

\author{
Kseniya Tver'yanovich \\ Institute of Russian Literature (Pushkinskij Dom) / \\ Russian Academy of Sciences, Saint Petersburg, Russia \\ ksutver@gmail.com \\ (1) 0000-0001-9831-8129
}

\begin{abstract}
The combination of certain rhythmical forms and similar grammatical structures in Russian iambic tetrameter was first noted in the 1920s by scholars such as Sergey Bobrov and especially Osip Brik, who detected its presence across the oeuvres of different authors. Decades later, drawing on his own data about the parts of speech in Russian language and verse, Mikhail Gasparov claimed that rhythmical and grammatical stereotypes occurred in Russian classical meter because each ictus could naturally only accommodate certain words or grammatical forms based on their length or accentual structure. Together with his co-author, Tatiana Skulachyova, Gasparov discovered, for example, that Russian adjectives and verbs tended to be longer than an iambic foot and therefore to occupy ictuses that lacked any metrical stresses. By creating preferred verse locations for certain parts of speech, this also strongly influenced the syntax of the iambic line. This paper considers new data about parts of speech that behave atypically from the standpoint of Gasparov's schema. For some of the authors and periods concerned, longer forms tend to fit into shorter syllabic slots and vice versa. My overview and analysis are based on data regarding iambic tetrameter in the work of two Russian poets from the early 20th century. I conclude that verse is an intricate system in which the rhythmical vocabulary of parts of speech-that is, their typical syllabic length and stress locations-does not necessarily prevail over other important factors. Those factors may ultimately determine the content of rhythmical structures.
\end{abstract}

\section{Introduction}

In the late 1910s, Russian scholars began to show a growing awareness that the vocabulary of each iambic foot naturally favored certain accentual and syllabic word types. In his articles on Pushkin's iambic tetrameter (1918) and pentameter (1919-1923), Boris Tomashevskij (2007a,b) presented data about the various rhythmical and syllabic word variations encountered in each foot of the two iambic meters. A few years later, Sergej Bobrov $(1922,1925)$ argued that the prevalence of certain words in certain parts of iambic verse reflected syntactic and rhythmical stereotypes. Osip Brik advanced similar ideas. In a 
famous article on rhythm and syntax, Brik (1927) claimed that the repetition of syntactic structures in Russian iambic tetrameter was not the result of literary borrowings or influences. Rather these patterns were imminent to the structure of the verse itself since the rhythm provided for only limited possibilities or lexical and syntactic structures.

Although initiated around a century ago, this discussion did not produce any significant developments until the publication of the works of Mixail Gasparov in the 1980s, which led to further studies with his co-author, Tatyana Skulachyova. In an influential paper on verse linguistics, Gasparov (1996) applied Boris Yarxo's (1927) thesis that verse consists of a complex of various rhythmical levels. On this basis, he argued that verse theory should focus on the interrelationship of different levels rather than on any isolated trends at specific levels of rhythm. Of all the interconnections, those between accentual and grammatical rhythms attracted most attention since they also affected the vocabulary of verse and especially that of rhyme. Among other fruitful ideas, Gasparov (1984, 2000, 2004) offered a typology of rhythmical and grammatical verse stereotypes and a general explanation of their origins. Gasparov and Skulachyova (2004, pp. 51-61) also presented a "rhythmical dictionary of the parts of speech". This used prose works by Pushkin, Gogol', Turgenev, Tolstoj, and Chexov to estimate the average syllable lengths of different parts of speech and the average locations of stressed syllables in those various parts.

In the Russian language, the average word contains close to three syllables although this figure can range from one to around a dozen. Because the full syllabic count of a word includes not only its root but also any affixes and inflexions, this count depends on the word or word form's grammatical features. The same is true of the location of the stress, which is mobile in Russian. As such, the accentual and syllabic structures of Russian words can often be predicted based on their grammatical features.

According to Gasparov and Skulachyova (2004, p. 63), verbs and adjectives have especially distinct profiles in this respect. Not only are they the longest parts of speech in Russian but they also inversely reflect one another: adjectives tend to bear the stress on one of their initial syllables while verbs, in contrast, tend to carry the stress closer to their ending.

In Russian iambic verse, adjectives and verbs are therefore often expected to occupy pyrrhic feet so as to reserve that space for their long unstressed beginnings or endings. One important difference between these two parts of speech is that while in adjectives, the stressed syllable tends to precede the pyrrhic foot, in verbs, the stress tends to follow the pyrrhic foot. In their work on the grammar of Russian verse, Gasparov and Skulachyova (2004, pp. 6290) highlight this "inverse relationship" between the accentual structures of adjectives and verbs as a generally expected feature of the iambus.

This paper, however, focuses on examples where this expectation is not met and then looks into possible reasons for that failure. To that end, I focus on the poetry of Anna Axmatova and Osip Mandel'shtam, two prominent authors of the Silver Age, a period of extensive formal experimentation and great revision of 19th-century traditions. The discussion that follows is based on data for the parts of speech found in these poets' use of iambic tetrameter, generally the most 
popular and best-studied Russian classical meter. Although the poetry of the Silver Age tended to break with the classical iambic tradition, these two authors often applied it since it was, among other things, a way of contextualizing their own poems and themes.

\section{Materials and Methods}

Because grammatical structures and relationships may depend on factors such as strophic composition, my research for this paper was limited to quatrains of iambic tetrameter with alternate rhymes. In particular, I considered cases where the feminine clausulae in odd lines alternated with the masculine clausulae in even lines (I4 AbAb).

My selection of appropriately structured poems was based on the Russian National Corpus (RNC). For Axmatova, this produced 26 poems or 360 lines with composition dates ranging from 1910 to 1964. For Mandel'shtam, it generated 33 poems or 564 lines whose composition dated from 1909 to 1937.

For all of these poems, each line was manually annotated based on the following parameters:

- rhythmic form of iambic tetrameter (location of the pyrrhic foot),

- types of word boundaries (number of unstressed syllables following a stress), and

- parts of speech in each stressed foot.

The annotation of parts of speech was based mainly on the universal typology developed by the authors of the Universal Dependencies (UD) project, which relies on Universal Stanford Dependencies (Marneffe et al. 2014). In addition, I used Google's universal tags system for parts of speech (Petrov et al. 2012) and Daniel Zeman's (2008) universal conversion method for tag systems. ${ }^{1}$ Nevertheless, a number of modifications were required in order to adapt the system to the task of tracking phonetic words (i.e. content words together with their clitics) with a focus on only those cases where the main stress falls on an ictus. These modifications also needed to ensure compatibility with the results previously obtained by Gasparov and Skulachyova. In particular, the grammatical annotation excluded 1) all function words whatsoever and 2) any content words located between ictuses. Furthermore, in line with Gasparov's approach, Russian participles were tagged as adjectives rather than verbs since the syllabic and accentual structure of participles is generally the same as that of adjectives. This also makes their behavior adjective-like in the iambic environment.

1 The following abbreviations are used in tables in this paper: $\mathrm{PoS}=$ part of speech; ADJ = adjectives, participles, and ordinal numerals; ADP = adpositions; ADV = adverbs; AUX = auxiliary verbs; CCONJ = coordinate conjunctions; $\mathrm{DET}=$ pronominal adjectives and numerals; INTJ = interjections; NOUN = nouns; $\mathrm{NUM}=$ cardinal numerals; $\mathrm{PART}=$ particles; $\mathrm{PRON}=$ pronouns; $\mathrm{PROPN}=$ proper nouns; $\mathrm{SCONJ}=$ subordinate conjunctions; $\mathrm{VERB}=$ verbs; $\mathrm{X}=$ other. 


\begin{tabular}{|c|c|c|c|c|c|c|c|c|}
\hline \multirow[b]{2}{*}{ Author } & & \multicolumn{6}{|c|}{ Rhythmic form } & \multirow[b]{2}{*}{ Total } \\
\hline & & 1 & 2 & 3 & 4 & 5 & 6 & \\
\hline \multirow{2}{*}{ Axmatova } & no. & 97 & 26 & 44 & 148 & 6 & 39 & 360 \\
\hline & $\%$ & 26.9 & 7.2 & 12.2 & 41.1 & 1.7 & 10.8 & 100 \\
\hline \multirow{2}{*}{ Mandel'shtam } & no. & 89 & 60 & 81 & 241 & 20 & 73 & 564 \\
\hline & $\%$ & 15.8 & 10.6 & 14.4 & 42.7 & 3.5 & 12.9 & 100 \\
\hline
\end{tabular}

Table 1: Rhythmic profile of iambic tetrameter in AbAb stanzas by Axmatova and Mandel'shtam

\section{Results and Discussion}

In Russian iambic tetrameter, rhythm depends primarily on the distribution of actual word stresses along ictuses in an iambic line. Based on the location of ictuses without any stress (i.e. pyrrhic feet), Kirill Taranovskij (1953) offered the following classical typology of rhythmical forms in iambic tetrameter:

- form 1: $\cup-\cup-\cup-\cup-(\cup)$;

- form 2: $\cup \cup \cup-\cup-\cup-(\cup)$;

- form 3: $\cup-\cup \cup \cup-\cup-(\cup)$;

- form 4: $\cup-\cup-\cup \cup \cup-(\cup)$;

- form 5: $\cup-\cup \cup \cup \cup \cup-(\cup)$;

- form 6: $\cup \cup \cup-\cup \cup \cup-(\cup)^{2}$

Table 1 highlights the frequency of these forms in the material considered in this paper.

The current study explores the distribution of verbs and adjectives in each of these forms with one pyrrhic foot, i.e. forms 2,3 , and 4 . In the following sections, I therefore compare my new data about Axmatova and Mandel'shtam with Gasparov and Skulachyova's (2004, pp. 62-90) data about "Evgenij Onegin" by Aleksandr Pushkin. I, thus, highlight where these scholars' conclusions based on Pushkin's material apply to the 20th-century poets and where differences arise. $^{3}$

\subsection{Form 2: $\cup \cup \cup-\cup-\cup-(\cup)$}

Gasparov and Skulachyova argue that in form 2, it is very likely that adjectives will avoid foot 2 because there is no space for their stressed "head" before the pyrrhic foot. This is also due to the very strong syntactic link that adjectives

$2 \cup$ represents an unstressed syllable and - represents a stressed ictus.

3 It must be noted that the strophic structure of Pushkin's poem is very peculiar (14 lines of iambic tetrameter in a scheme AbAbCCddEffEgg). As such, it clearly differs from the structure of the poems by Axmatova and Mandel'shtam considered in this paper. 


\begin{tabular}{llcccc}
\hline \multirow{2}{*}{ Author } & & \multicolumn{3}{c}{ Foot } & \\
\cline { 3 - 5 } & PoS & 2 & 3 & 4 & Total \\
\hline Axmatova & ADJ & 2 & 3 & 3 & 8 \\
& VERB & 13 & 4 & 7 & 24 \\
Mandel'shtam & ADJ & 12 & 8 & 6 & 26 \\
\multirow{2}{*}{ Pushkin } & VERB & 24 & 7 & 11 & 42 \\
& ADJ & 32 & 41 & 39 & 112 \\
& VERB & 162 & 41 & 52 & 255 \\
\hline
\end{tabular}

Table 2: Form 2-No metrical stress in foot 1

create with the nouns to which they are attributed. Since such strong links tend to close the line, foot 4 is often occupied by nouns while foot 3 provides a natural home for adjectives. On the other hand, the rhythmical environment of foot 2 is perfectly suited for verbs with their long unstressed head and stressed ending. In form 2, foot 2 is therefore occupied by verbs about twice as often as any other part of speech. Moreover, verbs appear in this position three to four times as often as they do in any other foot (Gasparov and Skulachyova 2004, p. 76). The pattern is well illustrated by the data for Pushkin's "Yevgenij Onegin" (Gasparov and Skulachyova 2004, p. 85), as cited in Table 2.

Some of the differences among the three poets noted here and further on in this paper may be due to random distributions. Furthermore, since the selections from Axmatova and Mandel'shtam are relatively small, the conclusions reached about them may not be as indisputable as those about Pushkin. Axmatova's verse in form 2 contains very few adjectives and the data are therefore insufficient to trace any trends. In Mandel'shtam'scase, however, not only do adjectives prefer foot 2 over any other location in form 2 but they are only outnumbered twofold in that slot by verbs. Moreover, around half of Mandel'shtam's adjectives prefer foot 2, roughly the same frequency we see in his verbs. Such a result, however, contradicts the rhythmical and grammatical nature of adjectives proposed by Gasparov and Skulachyova.

To occupy foot 2 in this form, an adjective must be four or five syllables long with the stress on the fourth syllable $(\cup \cup \cup-$ or $\cup \cup \cup-\cup)$. This is a structure more typical of verbs, the so-called rhythmical opposites of adjectives. The question, thus, arises how this situation is possible when the average Russian adjective has a short stressed head and a long unstressed ending. To find an answer, we need to consider Mandel'shtam 's samples more closely.

To begin with, we find that 10 out of the 12 adjectives located at the start of form 2 extend their rhythmical heads by one additional syllable. This occurs through the incorporation of enclitics (Table 3).

In contrast, the ending is shortened because of the use of the short forms of the adjectives, as can be seen in five out of the 12 lines. This also explains why the above samples are hardly affected by the syntactic attraction of adjectives to the end of the line, i.e. the second major explanation for Russian adjectives' tendency to avoid feet 1 and 2. Specifically, short adjectives play a different syntactic role 


\begin{tabular}{lcccc}
\hline & \multicolumn{4}{c}{ Ictus } \\
\cline { 2 - 5 } Line & 1 & 2 & 3 & 4 \\
\hline И голубая нитка славы & 0 & ADJ & NOUN & NOUN \\
И широка моя стезя - & 0 & ADJ & DET & NOUN \\
Средь голубых шумят стихий. & 0 & ADJ & VERB & NOUN \\
На громовой призыв скрепясь: & 0 & ADJ & NOUN & VERB \\
Изображен грядущий день. & 0 & ADJ & ADJ & NOUN \\
Свой изначальный сон дробя. & 0 & ADJ & NOUN & VERB \\
Хоть говоривший мне о Риме & 0 & ADJ & PRON & NOUN \\
Кто незнаком с буфетным знаком & 0 & ADJ & ADJ & NOUN \\
Мы недовольны светом солнца, & 0 & ADJ & NOUN & NOUN \\
На деревянных лавках спят. & 0 & ADJ & NOUN & VERB \\
Как нежилого сердца дом, - & 0 & ADJ & NOUN & NOUN \\
Озарены луной ночевья & 0 & ADJ & NOUN & NOUN \\
\hline
\end{tabular}

Table 3: Form 2-Adjectives in foot 2 in Mandel'shtam's work

\begin{tabular}{llcccc}
\hline & & \multicolumn{3}{c}{ Foot } & \\
\cline { 3 - 5 } Author & PoS & 1 & 3 & 4 & Total \\
\hline Axmatova & ADJ & 9 & 12 & 5 & 26 \\
& VERB & 10 & 11 & 6 & 27 \\
Mandel'shtam & ADJ & 17 & 20 & 6 & 43 \\
\multirow{3}{*}{ Pushkin } & VERB & 19 & 17 & 5 & 41 \\
& ADJ & 68 & 82 & 42 & 192 \\
& VERB & 118 & 154 & 56 & 328 \\
\hline
\end{tabular}

Table 4: Form 3-No metrical stress in foot 2

in Russian: unlike longer adjectives, which are generally attributes, the shorter forms serve as predicates. They therefore tend to behave more like verbs and skew closer to the beginning of the line.

\subsection{Form 3: $\cup-\cup \cup \cup-\cup-(\cup)$}

According to Gasparov and Skulachyova, in form 3, verbs are very common in the pyrrhic foot and their stressed syllable tends to fall in foot 3. Adjectives occupy the pyrrhic foot less often with their unstressed ending - they occur in foot 1 about half as often as verbs occur in foot 3-and are more attracted to foot 3 for syntactic reasons (Gasparov and Skulachyova 2004, p. 77); cf. Table 4.

In our samples from the two 20th-century poets, there is also clear evidence of the adjectival attraction to foot 3; this is not the case for verbs. In fact, in Mandel'shtam's case, there are fewer verbs in foot 3 than in foot 1, a pattern contrary to the average rhythmical structure. In Axmatova's case, verbs occur 
in feet 1 and 3 at around the same frequency. In Table 5 we find examples from both poets.

Interestingly, for Mandel'shtam, about every third line in the list above (seven lines out of 19) starts with a verb form that has an atypical rhythmic structure where the stress occurs closer to the beginning $(\cup-\cup \cup$ or $\cup-\cup \cup \cup)$. Of the remaining 12 verb forms that start lines, 11 have a symmetrical structure $(\cup-\cup)$ and one includes only two syllables with the stress on the second one $(\cup-)$. For Axmatova, on the other hand, the picture is quite different: of the lines listed in Table 5, only one starts with a verb form that has an extended unstressed ending (I slushala yazy'k rodnoj $\cup-\cup \cup$ ) while eight initial verbs are symmetrical $(\cup-\cup)$. In other words, for Axmatova, unlike for Mandel'shtam, it is not the ending of the verb form in foot 1 that occupies the pyrrhic foot 2, but rather the beginning of whichever part of speech has its stressed syllables in foot 3 (in most cases, a noun).

Another difference between Mandel'shtam's verbs and Axmatova's respective verb choices in foot 1 of form 3 is that whereas Mandel'shtam clearly prefers the present tense (seven lines out of 19), Axmatova is more inclined to use the past tense (four lines out of 10). Not surprisingly, the same is true of the verbs in foot 3, as can be seen from Table 6 where Axmatova's verbs are distributed evenly across the past, present, and all other verb forms. Meanwhile for Mandel'shtam, eight verbs are in the present tense and the remaining nine take either past, future, infinitive, imperative, or adverbial forms.

In another intriguing difference, we find that for Axmatova, 10 of the 11 verb forms that occupy foot 3 have a typical rhythmic structure, i.e. a longer unstressed head and shorter stressed ending; the most frequently encountered version of this is $\cup \cup-(\cup)$ (9 verb forms of 11). For Mandel'shtam, however, only seven of the 17 verb forms have a typical rhythmic structure. In contrast, 10 of the verbs are either symmetrical $\cup-\cup$ (four instances) or shorter forms with only two syllables ( $\cup-$ or $-\cup$; six instances in total). The seven typical ones have the structure $\cup \cup-(\cup)$ and $\cup \cup \cup-\cup$ of which there are five and two cases, respectively.

\subsection{Form 4: $\cup-\cup-\cup \cup \cup-(\cup)$}

In form 4, adjectives generally predominate in the pyrrhic foot 3 and locate their stressed syllable in foot 2 for both rhythmical and syntactical reasons (Gasparov and Skulachyova 2004, pp. 67, 78, 79). This is the case for all three of the poets considered (see Table 7).

As for verbs, for rhythmical reasons, they are less easily accommodated in foot 2 than foot 4 . The latter is, in contrast, well suited to their stressed ending while the preceding pyrrhic easily contains their long unstressed head. Foot 1 is also quite attractive for verbs although this is largely for syntactic reasons (Gasparov and Skulachyova 2004, p. 66). These trends are well illustrated by the data for Pushkin and Axmatova in Table 7 and. In Mandel'shtam's case, however, syntactic considerations seem somehow to override rhythmical ones. As such, although foot 4 is especially suited to the typical verb structure, i.e. a 
(a) Mandel'shtam

\begin{tabular}{lcccc}
\hline & \multicolumn{4}{c}{ Ictus } \\
\cline { 2 - 5 } Line & 1 & 2 & 3 & 4 \\
\hline Мы ринулись в зеленый омут. & VERB & 0 & ADJ & NOUN \\
И вскакивать на жесткой койке, & VERB & 0 & ADJ & NOUN \\
Вернуться на родной фрегат! & VERB & 0 & ADJ & NOUN \\
Работает в табачной мгле - & VERB & 0 & ADJ & NOUN \\
И дышит в роковых страстях. & VERB & 0 & ADJ & NOUN \\
Пустеет понемногу сад. & VERB & 0 & ADV & NOUN \\
Чтоб ладилась моя работа & VERB & 0 & DET & NOUN \\
И крепла - на борьбу с врагом. & VERB & 0 & NOUN & NOUN \\
Я слышу отреченья скрежет: & VERB & 0 & NOUN & NOUN \\
Кто выменял коня - событий & VERB & 0 & NOUN & NOUN \\
Косится на бочонок вождь. & VERB & 0 & NOUN & NOUN \\
Не хватит на мешки рогож, - & VERB & 0 & NOUN & NOUN \\
Плетется на асфальте воз. & VERB & 0 & NOUN & NOUN \\
Чернеет на скале гранитной & VERB & 0 & NOUN & ADJ \\
Напомнила твой образ, скиф! & VERB & 0 & NOUN & NOUN \\
Обманывает нас в мечтах, & VERB & 0 & PRON & NOUN \\
Я шел, не опуская глаз. & VERB & 0 & VERB & NOUN \\
И, мнится, заворкует вдруг. & VERB & 0 & VERB & ADV \\
Рыдая, обнимает дочь & VERB & 0 & VERB & NOUN \\
\hline
\end{tabular}

(b) Axmatova

\begin{tabular}{lcccc}
\hline & \multicolumn{4}{c}{ Ictus } \\
\cline { 2 - 5 } Line & 1 & 2 & 3 & 4 \\
\hline Но знайте: не пройдет вам даром & VERB & 0 & VERB & ADV \\
Приходит долгжданный час. & VERB & 0 & ADJ & NOUN \\
Прощаясь, помахал рукой & VERB & 0 & VERB & NOUN \\
Звенели голоса детей, & VERB & 0 & NOUN & NOUN \\
Качаясь на волнах эфира, & VERB & 0 & NOUN & NOUN \\
И знаем, что в оценке поздней & VERB & 0 & NOUN & ADJ \\
Смотри, как глубоко ныряю, & VERB & 0 & ADV & VERB \\
Истлело в глубине зеркал... & VERB & 0 & NOUN & NOUN \\
И слушала язык родной. & VERB & 0 & NOUN & ADJ \\
Увидел с высоты Кремля, & VERB & 0 & NOUN & NOUN \\
\hline
\end{tabular}

Table 5: Form 3-Verbs in foot 1 
(a) Mandel'shtam

\begin{tabular}{lcccc}
\hline & \multicolumn{4}{c}{ Ictus } \\
\cline { 2 - 5 } Line & 1 & 2 & 3 & 4 \\
\hline Цветочную ли холить грядку, & ADJ & 0 & VERB & NOUN \\
Кандальную дробите цепь! & ADJ & 0 & VERB & NOUN \\
Расширенный пустеет взор, & ADJ & 0 & VERB & NOUN \\
Клубящаяся стынет пена, & ADJ & 0 & VERB & NOUN \\
Прозрачными стоят деревья, & ADJ & 0 & VERB & NOUN \\
Такую причинить обиду & DET & 0 & VERB & NOUN \\
Товарищи лежат в бреду. & NOUN & 0 & VERB & NOUN \\
Был деятель. Глядясь в себя, & NOUN & 0 & VERB & PRON \\
И голубь не боится грома, & NOUN & 0 & VERB & NOUN \\
В палатки призывал народ. & NOUN & 0 & VERB & NOUN \\
У вечности ворует всякий, & NOUN & 0 & VERB & PRON \\
Нас пеною воздвигнул случай & NOUN & 0 & VERB & NOUN \\
И мне повиновалось пламя - & PRON & 0 & VERB & NOUN \\
Я шел, не опуская глаз. & VERB & 0 & VERB & NOUN \\
И, мнится, заворкует вдруг. & VERB & 0 & VERB & ADV \\
Рыдая, обнимает дочь... & VERB & 0 & VERB & NOUN \\
Мне холодно, я спать хочу; & X & 0 & VERB & VERB \\
\hline & & & & \\
\end{tabular}

(b) Axmatova

\begin{tabular}{lcccc}
\hline & \multicolumn{4}{c}{ Ictus } \\
\cline { 2 - 5 } Line & 1 & 2 & 3 & 4 \\
\hline Родимый охраняет край, & ADJ & 0 & VERB & NOUN \\
Ты призрачным сияла светом, & ADJ & 0 & VERB & NOUN \\
Пусть горько улыбнутся губы, & ADV & 0 & VERB & NOUN \\
Зачем вы отравили воду & ADV & 0 & VERB & NOUN \\
Я горько вспоминаю вас. & ADV & 0 & VERB & PRON \\
Чем нынче и живет и дышит & ADV & 0 & VERB & VERB \\
Сегодня показался мне. & ADV & 0 & VERB & PRON \\
И дом припоминая темный & NOUN & 0 & VERB & ADJ \\
Как все здесь говорит о мире, & PRON & 0 & VERB & NOUN \\
Но знайте: не пройдет вам даром & VERB & 0 & VERB & ADV \\
Прощаясь, помахал рукой & VERB & 0 & VERB & NOUN \\
\hline
\end{tabular}

Table 6: Form 3-Verbs in foot 3 


\begin{tabular}{llcccc}
\hline & & \multicolumn{3}{c}{ Foot } & \\
\cline { 3 - 5 } Author & PoS & 1 & 2 & 4 & Total \\
\hline Axmatova & ADJ & 18 & 68 & 18 & 104 \\
& VERB & 25 & 13 & 23 & 61 \\
Mandel'shtam & ADJ & 39 & 83 & 24 & 146 \\
& VERB & 50 & 38 & 35 & 123 \\
Pushkin & ADJ & 254 & 719 & 330 & 1303 \\
& VERB & 464 & 344 & 547 & 1355 \\
\hline
\end{tabular}

Table 7: Form 4-No metrical stress in foot 3

long unstressed head and stressed ending, it appears to accommodate verbs even less often than foot 2 (Table 8).

Foot 4 is the only location considered in form 4 where Mandel'shtam's verbs occur more often in the past tense than the present (11 vs. nine instances). This is also very close to the picture for Axmatova (Table 9, seven vs. five instances). For both poets, the verb forms in foot 4 have a typical rhythmical structure in about one half of all of their lines in form 4. In Mandel'shtam's case, this amounts to slightly less than one half of the lines (17 cases out of 35) while for Axmatova, it is slightly more than one half (13 cases out of 23). Among other factors, this is because the rhythmic head of Axmatova's verbs is more often extended owing to the use of clitics (this occurs in seven out of 23 lines for Axmatova compared to four out of 35 lines for Mandel'shtam).

\subsection{Conclusion}

Although Gasparov and Skulachyova's conclusions were based on just one author's use of iambic tetrameter, their explanations of the trends they observed referred to the general properties of Russian parts of speech, primarily verbs and adjectives. Moreover, they explicitly argued that the effects of grammar on rhythm and vice versa were determined by language. Their arguments, thus, implied that the trends seen in Pushkin's work could be expected in any other Russian poet's use of iambic tetrameter. This assumption persisted despite their acknowledgment that a complete understanding of interactions between rhythm and grammar in verse would require more extensive samples of poetry in Russian and other languages (Gasparov and Skulachyova 2004, p. 80).

Against this, my comparison of the grammar and rhythm of the iambic tetrameter samples in forms 2, 3, and 4 for Axmatova and Mandel'shtam shows that although the patterns discovered in Pushkin's work are well supported by Gasparov and Skulachyova's "grammatical-rhythmical dictionary" (2004, pp. 51-61), they only apply with significant limitations. In particular, they hold when dominant verbs and adjectives have a standard rhythmical structure, direct word order is followed, and syntactic inversions are avoided. These conditions are not always met, however, and they tend to be missing from the 


\begin{tabular}{|c|c|c|c|c|}
\hline \multirow[b]{2}{*}{ Line } & \multicolumn{4}{|c|}{ Ictus } \\
\hline & 1 & 2 & 3 & 4 \\
\hline И светом ласковым сиял. & NOUN & $\mathrm{ADJ}$ & 0 & VERB \\
\hline Священник римский уцелел. & NOUN & ADJ & 0 & VERB \\
\hline В стропилах каменных исчез. & NOUN & $\mathrm{ADJ}$ & 0 & VERB \\
\hline Копыта конские твердят. & NOUN & ADJ & 0 & VERB \\
\hline Оркестр торжественный настройте, & NOUN & $\mathrm{ADJ}$ & 0 & VERB \\
\hline Того, кто вовремя застыл. & DET & ADV & 0 & VERB \\
\hline Как кони медленно ступают, & NOUN & $\mathrm{ADV}$ & 0 & VERB \\
\hline Душа томительно живет. & NOUN & $\mathrm{ADV}$ & 0 & VERB \\
\hline И, если подлинно поется & SCONJ & ADV & 0 & VERB \\
\hline Не мог сильнее тосковать! & VERB & $\mathrm{ADV}$ & 0 & VERB \\
\hline Листы, которые умрут, & NOUN & DET & 0 & VERB \\
\hline Лесной вершине передать. & $\mathrm{ADJ}$ & NOUN & 0 & VERB \\
\hline Ты желтый сумрак предпочла. & $\mathrm{ADJ}$ & NOUN & 0 & VERB \\
\hline Слух чуткий парус напрягает, & $\mathrm{ADJ}$ & NOUN & 0 & VERB \\
\hline В священном сумраке исчез! & $\mathrm{ADJ}$ & NOUN & 0 & VERB \\
\hline Одна пустыня пролегла. & ADJ & NOUN & 0 & VERB \\
\hline Впервые силой изошла. & ADV & NOUN & 0 & VERB \\
\hline Обратно в степи привела... & ADV & NOUN & 0 & VERB \\
\hline Когда рябина, развивая & $\mathrm{ADV}$ & NOUN & 0 & VERB \\
\hline И будешь сталинкою зваться & AUX & NOUN & 0 & VERB \\
\hline Которым церковь говорит; & DET & NOUN & 0 & VERB \\
\hline Ее лица ни покрывайте - & DET & NOUN & 0 & VERB \\
\hline В театре публики лежало & NOUN & NOUN & 0 & VERB \\
\hline Сквозь рощу портиков идешь. & NOUN & NOUN & 0 & VERB \\
\hline у Чарльза Диккенса спросите, & NOUN & NOUN & 0 & VERB \\
\hline O, время, завистью не мучай & NOUN & NOUN & 0 & VERB \\
\hline Он только сердце веселит. & PART & NOUN & 0 & VERB \\
\hline Как трудно раны врачевать! & $\mathrm{X}$ & NOUN & 0 & VERB \\
\hline И, как ее ни называйте & $\mathrm{ADV}$ & PRON & 0 & VERB \\
\hline И мы его обороним: & PRON & PRON & 0 & VERB \\
\hline А мне уж не на кого дуться & PRON & PRON & 0 & VERB \\
\hline О, как мы любим лицемерить & $\mathrm{ADV}$ & VERB & 0 & VERB \\
\hline И небо падает, не рушась, & NOUN & VERB & 0 & VERB \\
\hline И море плещет, не пенясь. & NOUN & VERB & 0 & VERB \\
\hline Зарделся, вспыхнул и погас. & VERB & VERB & 0 & VERB \\
\hline
\end{tabular}

Table 8: Form 4-Verbs in foot 4 (Mandel'shtam)

poetry of historical periods or literary movements preoccupied with formal experimentation.

Although the average Russian adjective, for example, is more than three syllables long and its main stress tends to fall close to the beginning of the word, this does not necessarily mean that these adjectives are always the most 


\begin{tabular}{lcccc}
\hline & \multicolumn{3}{c}{ Ictus } \\
\cline { 2 - 5 } Line & 1 & 2 & 3 & 4 \\
\hline За то, что я не говорила & DET & PRON & 0 & VERB \\
И дом, в котором не живем, & NOUN & DET & 0 & VERB \\
В ворота черные стучит. & NOUN & ADJ & 0 & VERB \\
И мнится мне, что уцелела & VERB & PRON & 0 & VERB \\
О смерти господа моля. & NOUN & NOUN & 0 & VERB \\
Страна великая живет, & NOUN & ADJ & 0 & VERB \\
Такой, что мне не разобрать, & DET & PRON & 0 & VERB \\
За то, что я не издевалась & DET & PRON & 0 & VERB \\
И в косах спутанных таится & NOUN & ADJ & 0 & VERB \\
Кто стать звенящими поможет & AUX & ADJ & 0 & VERB \\
Остаток юности губя, & NOUN & NOUN & 0 & VERB \\
Тростник оживший зазвучал. & NOUN & ADJ & 0 & VERB \\
Ничьих я слов не повторяю & DET & NOUN & 0 & VERB \\
Как ты до мая доживешь?” & PRON & NOUN & 0 & VERB \\
Оркестр веселое играет, & NOUN & ADJ & 0 & VERB \\
Где скромно ночи провожу, & ADV & NOUN & 0 & VERB \\
Мы что-то мудрое решали, & PRON & ADJ & 0 & VERB \\
Скрипач безносый заиграл. & NOUN & ADJ & 0 & VERB \\
Чтоб мне таинственно помочь. & PRON & ADV & 0 & VERB \\
Но Лишней я не назову. & ADJ & PRON & 0 & VERB \\
А ты мой дом благослови, & PRON & NOUN & 0 & VERB \\
От русской Церкви отлетал, & ADJ & NOUN & 0 & VERB \\
Я новым именем покрою & ADJ & NOUN & 0 & VERB \\
\hline & & & & \\
\hline
\end{tabular}

Table 9: Form 4-Verbs in foot 4 (Axmatova)

prevalent. The actual length of a Russian adjective can vary from one syllable to a dozen, and, although such extremes are rare, there is plenty of space for variation in between. The same holds true for other part of speech as well-the Russian vocabulary includes plenty of words that do not conform with the standard rhythmical scheme for their respective part of speech. Moreover, as can be seen from many of the examples in this paper, there are easy and logical ways to extend the rhythm structure of many parts of speech with clitics; these make the actual rhythmical structure of a word even less predictable since they add more variables. Due to its generally free word order, particularly in the case of poetry, Russian syntax also imposes no severe restrictions on rhythmical grammar.

Clearly the rhythmical-grammatical trends that Gasparov and Skulachyova discovered were apparent in their data just as their explanations were based in their rhythmical dictionary of parts of speech. Nevertheless my comparison reveals a more complex picture in which rhythmical grammar appears to belong to a more intricate system. The typical structures and syntactic roles of parts of speech are undoubtedly important but they are only some of a number 
of factors whose relative weights still need to be determined from more extensive and diverse material. These other significant factors may, for example, include general historical changes in language or style, an author's individual preferences, and strophic structure.

Finally, it must be noted that this paper's observations and conclusions are based on relatively limited selections from just two 20th-century poets. Further extension of the data and inclusion of other authors may eliminate the risks related to random distributions. This may also help us to better understand the nature and causes of the reported differences between the expected and real distributions of parts of speech in Russian iambic tetrameter.

\section{Acknowledgments}

The author is deeply indebted to Kirill Maslinskij and Kirill Muxin for their assistance with the automatic calculation of data for this paper and to the anonymous reviewers for their helpful comments.

\section{References}

Bobrov, Sergej (1922). "Zaimstvovaniya i vliyaniya: popy'tka metodologizacii voprosa”. In: Pechat' i revolyuciya 8, pp. 72-92.

Bobrov, Sergej (1925). "Zaimstvovaniya stixotvorny'ye”. In: Literatutnaya e'nciklopediya: Slovar' literaturny'x terminov 1. Moskva, Leningrad: Izdatel'stvo L. D. Frenkel', pp. 255-258.

Brik, Osip (1927). "Ritm i sintaksis: (Materialy' k izucheniyu stixotvornoj rechi)”. In: Novy'j LEF, pp. 3-6.

Gasparov, Mixail Leonovich (1984). "Ritmicheskij slovar' i ritmiko-sintaksicheskiye klishe”. In: Problemy' strukturnoj lingvistiki. Moskva, pp. 169-185.

Gasparov, Mixail Leonovich (1996). "Lingvistika stixa”. In: Slavyanskij stix: stixovedeniye, lingvistika I poe'tika. Moskva, pp. 5-17.

Gasparov, Mixail Leonovich (2000). “'Ty'-ty' rifmy'”: ritmiko-sintaksicheskiye klishe u Pushkina”. In: Posle yubileya. Ed. by Samuel Schwarzband and Roman Timenchik. Jerusalem: The Center for the Study of Slavic Languages and Literatures at the Hebrew University of Jerusalem, pp. 71-84.

Gasparov, Mixail Leonovich (2004). "Ritmiko-sintaksicheskiye klishe i formuly' v e'piloge "Ruslana i Lyudmily'”’. In: Slavyanskij stix VII: Lingvistika i struktura stixa. Ed. by Mixail Leonovich Gasparov and Tatyana Vladimirovna Skulachyova. Moskva: Yazy'ki slavyanskoj kul'tury', pp. 149-166.

Gasparov, Mixail Leonovich and Tatjana Vladimirovna Skulachyova (2004). Stat'i o lingvistike stixa. Moskva: Yazy'ki slavyanskoj kul'tury.

Marneffe, Marie-Catherine de, Timothy Dozat, Natalia Silveira, Katri Haverinen, Filip Ginter, Joakim Nivre, and Christopher D. Manning (2014). "Universal Stanford dependencies: A cross-linguistic typology”. In: Proceedings of the Ninth International Conference on Language Resources and Evaluation (LREC'14). Reykjavik: European Language Resources Association (ELRA), 
pp. 4585-4592. URL: http://www.lrec-conf.org/proceedings/lrec2014/pdf/ 1062_Paper.pdf.

Petrov, Slav, Dipanjan Das, and Ryan McDonald (2012). "A Universal Part-ofSpeech Tagset”. In: Proceedings of the Eighth International Conference on Language Resources and Evaluation (LREC'12). Istanbul: European Language Resources Association (ELRA), pp. 2089-2096. URL: http://www.lrec-conf.org/ proceedings/lrec2012/pdf/274_Paper.pdf.

RNC (2020). Russian National Corpus. URL: https://ruscorpora.ru/new/searchpoetic.html (visited on 11/15/2020).

Taranovskij, Kiril (1953). Ruski dvodelni ritmovi. Beograd: Srpska akademija nauka.

Tomashevskij, Boris Viktorovich (2007a). "Pyatistopny'j yamb Pushkina”. In: Izbranny'ye raboty' o stixe. Sankt-Peterburg, Moskva: Filologicheskij fakul'tet SPbGU, Izdatel'skij centr "Akademiya”, pp. 140-242.

Tomashevskij, Boris Viktorovich (2007b). "Ritmika chety'ryoxstopnogo yamba po nablyudeniyam nad stixom "Yevgeniya Onegina"”. In: Izbranny'ye raboty' o stixe. Sankt-Peterburg, Moskva: Filologicheskij fakul'tet SPbGU, Izdatel'skij centr "Akademiya", pp. 101-139.

UD (2020). Universal Dependencies. URL: https://universaldependencies.org/ (visited on 11/15/2020).

Yarxo, Boris (1927). "Prostejshiye osnovaniya formal'nogo analiza". In: Ars Poetica I. Moskva: Gosudarstvennaya akademiya xudozhestvenny'x nauk, pp. 7-29.

Zeman, Daniel (2008). "Reusable Tagset Conversion Using Tagset Drivers”. In: Proceedings of the Sixth International Conference on Language Resources and Evaluation (LREC'08). Marrakech: European Language Resources Association (ELRA). URL: http://www.lrec-conf.org/proceedings//rec2008/pdf/66_paper. pdf. 